\title{
Pemikiran Hanslick tentang Estetika dan Kritik Musik
}

\author{
Sunarto \\ Jurusan S-1 Pendidikan Seni, Drama, Tari, dan Musik, Fakultas Bahasa dan Seni, \\ Universitas Negeri Semarang, e-mail: sunartounnes@gmail.com
}

\begin{abstract}
Approaching the mid-19th century began the aesthetics of music, especially Western music aesthetics as an independent science apart from philosophy. In the development of musical aesthetics are always closely related between philosophy and the philosopher. Discussion on the aesthetics of music can not be separated from some of the theories that have been developed by philosophers. Eduard Hanslick is a figure in the history of musical aesthetics of music included in "Group Autonomis". This group believes that music is a world of sounds organized and stand alone without any. For him and the group, the music is not the language of emotions or feelings. He then gave a sharp criticism against some composers include Richard Wagner and Anton Bruckner as a representative "Group Heteronomis" who argue that music can be a means of expressing feelings, expressing ideas, or a certain atmosphere. According to the aesthetics of music is "absolute" (to the music itself). With absolutismenya, Hanslick criticized mercilessly composers heteronomis deems to have abused the music to be "programa" (music for something) -which he regarded as 'cheap music'. The rivalry between the two camps stream music aesthetics was known as The Great Debate.
\end{abstract}

Keywords: Aesthetics, Criticism, Autonomis, Heteronomis

\begin{abstract}
Abstrak
Mendekati medio abad ke-19 dimulailah estetika musik, khususnya estetika musik Barat sebagai sebuah ilmu yang mandiri terlepas dari filsafat. Dalam perkembangannya estetika musik selalu berkaitan erat antara filsafat dengan para filsufnya. Bahasan tentang estetika musik tidak bisa lepas dari beberapa teori yang telah dikembangkan oleh para filsuf. Eduard Hanslick merupakan tokoh estetika musik yang dalam sejarah musik dimasukkan dalam "Kelompok Autonomis". Kelompok ini berpendapat bahwa musik adalah suatu dunia suara terorganisir dan berdiri sendiri tanpa apapun. Baginya dan kelompok ini, musik bukan merupakan bahasa dari emosi atau perasaanperasaan. Ia kemudian memberikan kritik tajam terhadap beberapa komposer antara lain Richard Wagner dan Anton Bruckner sebagai wakil "Kelompok Heteronomis" yang berpendapat bahwa musik dapat merupakan suatu sarana untuk mengungkapkan perasaan-perasaan, mengungkapkan ide-ide, atau suasana tertentu. Menurutnya estetika musik adalah "absolut" (untuk musik itu sendiri). Dengan absolutismenya, Hanslick mengkritisi tanpa ampun para komposer heteronomis yang dianggapnya telah melecehkan musik hingga menjadi "programa" (musik untuk sesuatu) - yang dianggapnya sebagai 'musik murahan'. Perseteruan antara dua kubu aliran estetika musik itu dikenal sebagai The Great Debate.
\end{abstract}

Kata Kunci: Estetika, Kritik, Autonomis, Heteronomis.

\section{Pendahuluan}

Tulisan ini bersumber dari karya utama Eduard Hanslick, Vom MusikalischSchönen, yang telah diterjemahkan oleh Gustav Cohen dengan judul The Beautiful in Music, dan dipublikasikan pertamakali dalam edisi bahasa Inggris pada tahun 1891 oleh penerbit Novello and Company Ltd., London. Memang mengherankan mengapa buku yang telah lama diterbitkan dijadikan sumber utama penulisan. Ada beberapa alasan mengapa buku yang terbit tahun 1891 dipakai dalam tulisan ini. Pertama, buku ini merupakan buku pertamakali yang memberikan penilaian atau kritik musik secara ilmiah. Kedua, sekalipun buku ini telah terbit 125 tahun yang lalu, namun isinya masih 
dapat dipakai dan relevan sebagai bahan referensi atau panduan utama bagi kritik ilmiah dalam bidang musik.

The Beautiful in Music terdiri dari tujuh bab, yaitu: 1) Aesthetics as Founded on Feeling; 2) The Representation of Feeling is not the Subject of Music; 3) The Beautiful Music; 4) Analysis of the Subjective Impression of Music; 5) An Aesthetic Hearing as Distingueshed from a Pathological Hearing of Music; 6) Music in its Relation to Nature; dan 7) From Substance (Subject) as Applied to Music.

Hanslick adalah kritikus musik Austria dan sejarawan yang sangat pandai, ia merasa terpanggil menjadi kritikus dan penulis pada topik musik awal, menjadi salah satu kritikus musik pertama yang secara luas berpengaruh dalam pengertian modern, juga menjadi orang pertama penerima gelar profesor resmi dalam disiplin sejarah musik dan estetika musik dari Universitas Vienna pada tahun 1861. Risalah awalnya pada pertanyaan bentuk musik dan ekspresi (Vom Musikalisch-Schönen, 1854) yang menentang tradisi panjang pemikiran estetika, terletak pada esensi dan nilai musik yang longgar untuk didefinisikan sebagai 'ekspresi perasaan', dan hal itu tetap menjadi batu ujian dalam perdebatan estetika musik hingga sekarang. Sebagai seorang kritikus ia menutupi bagianlintas besar kehidupan musik di paruh kedua abad ke-19. Jurnalismenya tajam dan menghibur dalam gaya dan tetap menarik untuk sejarah serta wawasan kritis yang ditawarkannya (Maus, 1992:273-276).

\section{Pembahasan}

\section{Tentang Hanslick}

Eduard Hanslick (lahir di Praha, 11 September 1825; meninggal di Baden, Wina, 6 Agustus 1904) tidak terlepas dari ayahnya yang berasal dari keluarga berbahasa Jerman, seorang pemilik tanah kecil di Bohemia (Rakonitz/Rakovník). Hanslick senior, sang ayah, setelah pertama dilatih untuk menjadi pendeta kemudian memutuskan diri belajar filsafat, estetika, dan musik. Seorang pianis ulung dan penyanyi yang mendapatkan mata pencaharian dari mengajar musik dan bekerja paruh waktu untuk perpustakaan universitas. Bermodalkan hadiah lotre, sang ayah menikahi salah satu muridnya bernama Caroline, putri seorang pedagang Yahudi bernama Salomon Abraham Kisch. "Lotti" sebutan Caroline segera memeluk agama Katolik setelah pernikahannya. Eduard Hanslick menerima semangat ayahnya dalam karya-karya novel Perancis dan teater yang menyebabkan ia cenderung menggabungkan pemikiran kritis ilmiah dan musik.

Hanslick (Eduard) menerima pelatihan musik secara sangat baik dari Tomasek yang ia gambarkan sebagai 'Dalai Lama' dari musik Praha di era Vormärz (Deas, 1972:34). Ketika belajar di sekolah ia berkenalan dengan filsuf dan sejarawan musik Robert Zimmermann dan rekannya seorang kritikus bernama Ambros-keduanya seperti Hanslick-sedang belajar hukum untuk tujuan layanan sipil yang didukung begitu banyak warga kelas menengah dalam kekaisaran Austria. Dengan Ambros, ia segera mencurahkan banyak waktu luangnya untuk mencipta musik, belajar repertoar klasik hingga modern dan menulis kritik. Mulai tahun 1844 Hanslick sesekali menulis artikel kecil untuk jurnal Ost und West (dan suplemen sastra Prag), pada tahun 1846 menulis untuk Wiener Allgemeine Musik-Zeitung yang menampilkan kritik luas dan antusias tentang Tannhäuser karya Wagner, dari 1848 untuk Wiener Zeitung, Sonntagsblätter, dan jurnal-jurnal lainnya baik di dalam dan luar Wina (Maus, 1992:280).

Setelah menerima gelar sarjana hukum dari Universitas Vienna pada tahun 1849 ia mengambil pos sementara di kantor keuangan negara di Klagenfurt (1850-1852). Periode ini ia dianggap sebagai salah satu pengalaman spiritual seperti dalam pengasingan, tapi percakapan kultural dan 
keterampilan musik menjadikannya sebagai sosok yang diterima oleh masyarakat lokal. Komentarnya yang sinis dalam memoar pribadi: "Aku adalah Liszt dari Klagenfurt" (Deas, 1972:60) dikenal luas. Pada tahun 1852 Hanslick memperoleh bantuan dari kementerian keuangan untuk kembali ke Vienna dengan promosi jabatan dan segera setelah itu pindah ke posisiyang lebih baik dalam layanan pendidikan. Posisi ini membuatnya cukup waktu untuk melanjutkan aktivitasnya sebagai kritikus musik untuk ('kekaisaran') Wiener Zeitung pada tahun 1855. Ia juga menerbitkan tulisan-tulisan berpikiran liberal yang luas dan berpengaruh dalam Die Presse (Hall, 1995:87). Ketika dua sub-editor memisahkan diri untuk mendirikan Neuefreie Presse pada tahun 1864 Hanslick bergabung dengan mereka; ia tetap menjadi kritikus musik untuk penerbit itu sampai akhir karirnya. Sementara itu ia menghabiskan setiap sore hingga malam di perpustakaan dan di rumah untuk belajar berbagai nilai tentang estetika dan sejarah musik.

Hanslick secara ekstensif mengklaim telah memprovokasi dengan cara menulis refleksi diri tentang sifat 'yang indah dalam musik' (Vom Musikalisch-Schönen) sebagai cara berpikir korektifnya yang sangat longgar tentang musik dan perasaan. Tulisantulisannya yang berlebihan secara filosofis dan kultural tentang Wagner dan Liszt mulai berkembang sekitar waktu itu (Grey, 1998:35; Sams, 1975:868). Karakter meyakinkan dan argumen Hanslick yang bernafsu dengan cepat membawa bukunya ke perhatian seluruh Eropa yang berbahasa Jerman sehingga menghasilkan karya sastra yang cukup besar mendapatkan ulasan, sanggahan, dan revisi, serta beberapa pujian penting. Hanslick sendiri tidak mempublikasikan bukunya lebih lanjut atau esai tentang pertanyaan umum estetika musik, namun ia terus merevisi dan memperluas satu risalah singkat melalui berbagai edisi selanjutnya (McColl, 1997:27).
Pada tahun 1856 Universitas Vienna mengakui Vom Musikalisch-Schönen sebagai Habilitationsschrift dan menununjuk Hanslick sebagai dosen. Sejak saat itu hingga akhir 1890-an ia menawarkan kuliah reguler pada sejarah dan apresiasi musik. Pada tahun 1861 ia dipromosikan menjadi profesor sejarah dan estetika musik, dan mampu mengabdikan dirinya sepenuhnya untuk memberikan kuliah, urusan beasiswa, dan jurnalisme, menjadi dosen penuh pada tahun 1870 dan menerima gelar doctor honoris causa (McColl, 1997:76). Sebagai seorang kritikus yang mendapatkan penghormatan tinggi, Hanslick banyak diundang ke seluruh Eropa sebagai juri dalam kompetisi dan resital musik, sebagai wakil untuk konferensi musik dan isu-isu lainnya, dan tentu saja sebagai reporter pada urusan musik di ibu kota Eropa lainnya. Banyak dari paruh kedua memoarnya (Ausmeinem Leben) diambil dari catatan beberapa kunjungan Hanslick ke Paris, London, Milan, Roma, Berlin dan kotakota Jerman lainnya.

Di kota Wina nasihat Hanslick sering dinantikan sebagai keputusan resmi yang berkaitan dengan kehidupan musik kota, seperti pembangunan gedung opera baru pada tahun 1866, ia mengklaim telah berpendapat luas dengan pikiran yang mendukung termasuk tentang patung Wagner dan tokoh-tokoh musik harus dihormati di sana (Grey, 1994:55). Pada usia 51 Hanslick menikah dengan penyanyi muda Sophie Wohlmuth, muridnya selama beberapa waktu. Istrinya kemudian setuju untuk melupakan karir di panggung karena Hanslick berpendapat bahwa suara dan kesederhanaan duniawi tidak cocok untuknya. Penampilan suara sang isteri dibatasi hanya untuk ilustrasi vokal pada kuliahkuliah suaminya (Grey, 1988:37).

Pada tahun 1895, satu tahun setelah menyelesaikan memoarnya, Hanslick pensiun dari pekerjaan reguler sebagai kritikus dan dosen, meskipun demikian ia masih memberikan beberapa kuliah perdana 
yang terkenal hingga akhir abad tentang Verdi, Strauss dalam Zarathustra, Mahler dalam Gesellen dan lagu Wunderhorn, serta Zemlinsky dalam opera Es War Einmal. Ia memiliki Brahms dan Theodor Billroth yang tetap menjadi sahabat hingga tahun-tahun berikutnya (Grey, 1998:39).

\section{Estetika}

Ketenaran awal Hanslick sebagai penulis risalah perdebatan dalam Vom Musikalisch-Schönen kemudian dibayangi oleh ketenarannya sebagai antagonis kritis terkemuka terhadap Richard Wagner dan New School Jerman pada umumnya, ia menentang klaim mereka bahwa musik instrumental program dan symphonically throughput terdiri yang secara natural berdeklamasi bahwa 'drama musik' mewakili cara untuk masa depan musik (Ridley, 2004:70-75; Stock, 2007:158). Posisinya sebagai ahli estetika dan kritikus konservatif memainkan peran dalam reputasi anumerta meskipun sebagai ahli estetika itu telah menjadi perhatian yang lebih luas; sedangkan sebagai pembela untuk kelangsungan tradisi 'klasik' cenderung surut ke posisi kepentingan sejarah (Payzant, 1989:165). Dalam hal apapun, dua peran kongruen Hanslick dipandang sebagai lawan dari pembubaran melodi radikal dan konvensi formal dirayakan secara 'progresif' sebagai sarana untuk mencapai kebenaran ekspresif yang lebih besar atau artikulasi ideal, atau isi konseptual dari tujuan yang akan dinilai bermuka-muka dengan estetika Hanslick ini (Payzant, 1988-1989:130).

Inti dari risalah Hanslick adalah dalam tiga bab pertama, di sini ia memaparkan kekurangan logis dari 'estetika perasaan' tradisional yang telah mendominasinya untuk setidaknya 100 tahun (pasal 1) dan menyajikan sendiri 'tesis negatif' bahwa ekspresi atau representasi dari perasaan yang berbeda tidak dapat dianggap sebagai 'isi' dari musik atau dasar nilai estetika (bab 2); bahkan harus dicari dalam sifat-sifat 'sonically bergerak bentuk' sendiri (Tönendbewegte Formen)-sebagai alternatif, 'tesis positif' diuraikan dalam bab 3 (Hanslick, 1891:66-98). Lainnya adalah tesis positif, atau konsesi penting, dikembangkan dalam bab 2 (Hanslick, 1891:32-65): musik yang akan sering memiliki sifat dinamis karakteristik keadaan emosional yang berbeda, sedangkan korelasi tidak cukup langsung atau konsisten untuk memenuhi syarat sebagai representasi. Hanslick juga berpendapat bahwa kurangnya objek yang berbeda atau rujukan dalam kasus musik instrumental non-program membuat ekspresi yang berbeda, perasaan tertentu mungkin. Pembahasan 'kesan subjektif' musik (bab 4) mengantisipasi teori resepsi modern di membedakan antara sifat karya musik sebagai objek estetika dan aktivitas pendengar (Hanslick, 1891:99-121).

Hanslick menjunjung tinggi dalil otonomi estetika, menyatakan bahwa 'kontemplasi estetika tidak dapat didasarkan pada setiap situasi yang ada di luar karya seni itu sendiri'. Fondasi hadiah estetika formalis dalam pasal 3 dan 4 diperluas dalam bab kelima, yang membedakan antara kontemplasi estetika aktif musik sebagai 'komposisi' dan pasif, unreflective atau 'patologis' penerimaan musik stimulus suara belaka, terkait dengan estetika perasaan (respon subjektif terhadap kualitas akustik dan timbral dasar musik, Hanslick berpendapat, adalah di luar batas-batas analisis estetika yang tepat). Sepanjang tiga bab terakhir, dan yang paling eksplisit dalam satu akhir, Hanslick kembali ke masalah mengidentifikasi konten di musik independen dari struktur formal rinci. Benda-benda alam dan karakter sastra atau sejarah dan peristiwa tidak lebih dapat merupakan 'isi' Tujuan dari musik dari bisa emosi (atau perwakilan mereka). Ia memungkinkan bahwa 'ide tematik' mungkin ditafsirkan sebagai konten khusus musik yang diuraikan dalam bentuk yang lebih besar (bab 7) (Hanslick, 1891:160- 
174). Hasil bersih dari gagasan tematik sebagai dikerahkan dalam struktur keseluruhan akan menentukan kualitas estetika dan nilai pekerjaan, dan dapat diidentifikasi sebagai 'spiritual/ substansi intelektual'-nya (geistiger gehalt). Alternatif ini untuk kategori tradisional dari konten atau materi pelajaran dipandang sebagai lebih cocok untuk media musik; itu juga merupakan alternatif untuk tampilan Hegel musik sebagai ekspresi 'subjektivitas murni', unindividuated dan kurang jejak substansial pikiran atau roh (Hall, 1966-1967:436).

Tanggapan Torrent terhadap 'kontribusi terhadap revisi estetika musik' Hanslick ini radikal (seperti yang sub judul) mulai segera dan menunjukkan bahwa ia telah memukul saraf dalam pemikiran musik kontemporer. Sementara teori kritis Romantis sebelumnya mempersiapkan jalan bagi estetika seni otonom, dan sementara banyak filsuf dan generasi Hanslick sendiri bergeser kesetiaan mereka dari idealisme ke materialisme positivis, sedikit yang tercermin dalam penerimaan Vom Musikalisch-Schönen oleh musisi dan kritikus (McColl, 1997:57).

Beberapa kritikus, seperti: Lobe, Franz Brendel, khawatir bahwa sistem yang ketat, objektivitas sentimental Hanslick mengancam status baru kritik musik sebagai produk budaya yang signifikan. Lainnya, seperti Ferdinand Graf Laurencin (kenalan Wina), sengaja mengabaikan logika argumen Hanslick ini, didorong oleh rasa buta tugas sopan untuk membela kehormatan ekspresi musik. Meskipun Hanslick berdebat demi sebuah estetika 'khusus musik' yang akan bertanggungjawab untuk spesifikasi teknis dari medium, pendukung nya datang terutama dari jajaran filsuf dan penulis daripada musisi; di antara mereka adalah teman masa kecilnya: Robert Zimmermann, Hermann Lotzte, FT Vischer, Karl Köstlin, D.F. Strauss, dan orang Inggris, James Sully; tetapi juga teorikus musik Hauptmann dan peneliti akustik Helmholtz. Pada akhir abad ke-19 pengaruh gabungan dari Wagner, Schopenhauer, dan Nietzsche, pada pemikiran estetika Jerman cenderung merugikan bahkan filsuf profesional (seperti E. von Hartmann) serta ahli estetika musik (F. von Hausegger, F. Stade, Arthur Seidl) terhadap Hanslick, meskipun ia akhirnya mampu mengutip tulisan-tulisan kemudian Nietzsche membela sendiri anti-Wagnerisme (Sams, 1975:865).

Hanslick masih rutin dikutip sebagai godfather musik 'formalisme', tetapi jika risalahnya mungkin dikatakan untuk memberikan pembenaran filosofis untuk abad ke-20 sebagai analisis 'formalis', itu bukan suatu kegiatannya sendiri yang pernah dikejar atau sadar dipromosikan. Posisinya sendiri pada kapasitas musik untuk mewakili emosi atau untuk contoh karakter dan jenis lain dari 'ide' tetap menjadi bahan perdebatan, karena risalahnya yang tidak dogmatis atau sepenuhnya sistematis. Filsuf yang menganggap Hanslick semata-mata sebagai penulis Vom Musikalisch-Schönen mengabaikan sejauh mana ia datang untuk melihat argumen estetika sebagai akhirnya bawahan kekhasan sejarah dan budaya (Hall, 1967:445448). Namun, permintaan itu untuk wacana filosofis dan lebih bertanggung jawab dari musik 'ekspresi' terus menantang penulis dari semua jenis yang berusaha untuk mendeskripsikan, menganalisis dan menginterpretasikan music (Bowie, 2009:86-89; Hall, 1995:87-90).

\section{Kritik}

Sepanjang masa dewasanya karier utama Hanslick adalah sebagai kritikus musik. Ia seorang profesor di Universitas Vienna yang memberikan kuliah reguler dan melayani otoritas musik dalam berbagai kapasitas sipil dan tidak pernah berhenti membenamkan diri dalam sejarah musik dan mengajar praktik; tetapi selain dari risalah estetika dan kronika tentang lembaga dan 
kegiatan musik di Wina (Geschichte des Concertwesens di Wina, 1869) ia tidak menghasilkan karya ilmiah (Deas, 1972:90; McColl, 1977:64). Dari beberapa tahun di Praha dan Wina hampir sampai kematiannya, Hanslick konsisten melaporkan kehidupan musik zamannya dan itu dalam kapasitasnya bukan sebagai ahli estetika atau akademisi, tetapi ia dianggap sebagai semacam tokoh berpengaruh.

Sementara satu dapat mengamati dalam perjalanan karirnya pertumbuhan stabil dari kanon tetap 'klasik' di kedua gedung opera dan ruang konser, mayoritas kritiknya menyangkut karya-karya baru, lebih jarang kebangkitan karya dari 18 atau abad ke-19 sebelumnya. Meski begitu, perawatan dari perbendaharaan tua adalah instruktif sehubungan dengan kesadaran musik-historis berkembang dari hari (yang ia membuat kontribusi yang signifikan). Tidak seperti musik antiquarians sebagai Kiesewetter, Winterfeld, Baini, Anton Thibaut atau Ambros, Hanslick menunjukkan hampir tidak ada kepentingan dalam perbendaharaan dari sebelum 1700, dan apresiasi dari Bach dan Handel adalah yang terbaik yang sangat berkualitas (Robert Hirschfeld 1885 pamflet DaskritischeVerfahren E. Hanslicks mengecam kurangnya penerimaan untuk sang filsuf). Sementara itu sendiri, Hanslick skeptis dari orang-orang yang membuat tampilan saleh menghormati setiap musik mendahului klasik Wina; ia memandang upaya ilmiah Spitta, Chrysander dan Jahn, misalnya, sebagai cenderung ke arah pembelaan khusus, dan tidak merahasiakan pendapat rendah tentang Gluck 'khusus musik' bakat dan ragu elemen 'puritan' reformasi opera nya. Sebagai seorang sarjana dan dosen Hanslick melakukan menumbuhkan minat pada beberapa aspek praKlasik perbendaharaan; tapi itu justru keyakinan yang berkembang bahwa 'indah dalam musik' secara historis tergantung, yang mengatakan bahwa gaya musik dan sarana ekspresif didasarkan dalam konteks budaya- sejarah yang lebih luas, yang menyebabkan dia untuk membedakan antara perbendaharaan tua terutama antik bunga dan apa yang dianggap sebagai kanon yang modern yang layak (Clapham, 1971:241-246).

Peran instrumentalis virtuoso dan bintang opera internasional juga tumbuh pesat dalam hidup Hanslick, dan (karena ia mengeluh dalam memoar) bakat yang lebih rendah terus-menerus memancing untuk 'review yang baik di Wina' untuk meningkatkan pengajaran karir, bernyanyi, atau bermain di beberapa provinsi (Grey, 1998:35-39). Namun relatif sedikit ruang dalam tinjauan itu dikhususkan untuk kritik pertunjukan tertentu. Di antara pemain, penyanyi secara alami menerima perhatian yang besar, solois instrumental dan ansambel kamar lebih sedikit, sedangkan evaluasi kinerja orkestra, konduktor dan 'penafsiran' hampir tidak perhatian sama sekali. Kegiatan sebagai kritikus bergabung bukan dengan itu sebagai profesor dalam menggabungkan fungsi edukatif dan hiburan kritik untuk mempromosikan kesadaran budaya umum di kalangan masyarakat concert- dan operapergi (McColl, 1997:98-110).

Para pengikut mengingat Hanslick sebagai dari Brahms dan antagonis dari Wagner (bersama dengan Liszt dan identifikasi diri progresif lainnya). Sikapnya ke arah kedua komponis tersebut, lebih berpihak pada satu sisi daripada seperti pada umumnya, dan itu benar bahwa pada akhir karirnya, Hanslick menjadi seorang yang konservatif, berselera dan opininya tidak sesempit, searogan dan sekuno penghormatan dendam Wagner kepada sosok Beckmesser (dalam Die Meistersinger) yang dipercaya orang-orang. Hanslick mengapresiasi elemen Romantik dan 'Modern' Brahms seperti sebuah pengabadian dari bentuk instrumen Klasik (Sams, 1975:868) (Sams, 1975:868). Walaupun ia mendapat hanya sedikit penonton konser pada ulasannya, ia berulang kali membela tuntutannya, kualitas 
komposisi Brahms yang padat dan intelektual dan hak mereka untuk didengarkan ulang sebelum mendapatkan keputusan. 'Pesona' dari Simfoni Keempat yang ia akui, misalnya, adalah bukan merupakan 'sesuatu yang bersifat demokratis alami' (Ia mengaku yang Ketiga adalah kesukaannya). Hal ini sering dikatakan bahwa Hanslick tidak keberatan mengenai penerapan deskripsi afektif musik dalam tinjauannya sendiri, dan tidak ada kekurangan yang berarti, bahkan tentang metafora bunga dalam kritikannya untuk Brahms (pada kenyataannya, tidak ada dalam Vom Musikalisch-Schönen bahwa akan melarang penggunaan metafora interpretatif dalam kritik musik). Tetapi juga menarik untuk melihat bagaimana musik Brahms mendorongnya untuk merevisi tesisnya bahwa tema musik mungkin dianggap sebagai 'isi' yang penting dari komposisi: meninjau op. 99 F Mayor Cello Sonata dan A mayor Violin Sonata op. 100, ia memberhentikan fungsi cetakan tematik dalam mode, contoh 'program konser Inggris', “apa yang seseorang tahu dari seorang Brahms jika seseorang tahu hanya tema telanjangnya saja?" (Seolah-olah untuk membalas, ketika Brahms merevisi op. 8 Piano Trio-nya, di kemudian hari ia menghapus episode fugato yang menonjol dalam gerakan pertama yang telah digambarkan Hanslick sebagai 'ruang latihan sekolah Latin diinterpolasi menjadi puisicinta') Di atas semua itu, Hanslick tampaknya telah mengagumi Brahms sebagai sebuah musik dan 'spiritual' pewaris Schumann, yang musiknya berada paling dekat dengan hati Hanslick. Selama bertahun-tahun ia bermain karya piano Schumann sebelum akhirnya pensiun untuk beristirahat, untuk menenangkan pikiran dan 'membersihkan jiwanya' (katarsis) dari kegiatan harian: sekte puitis Romantis 'kebatinan' menjadi semacam ketaatan beragama pribadi (Kivy, 1993:65).
Sebuah sekte yang agak berbeda, bahwa Gesamtkunstwerk Wagner, memprovokasi oposisi Hanslick ini dengan tak hentihentinya. Memang, secara tertulis kemudian ia cenderung mengubah gaya oposisi terkenal untuk karya Wagner sebagai oposisi atas promosi diri komposer yang berlebihan dan retorika dogmatis dari 'sekte Wagner' (subjek esai sarkastis ditulis dalam kebangkitan Parsifal première tahun 1882). Anti-Wagner berpendirian untuk tetap berkembang dari motif campuran, kritis dan pribadi. Di satu sisi ia sangat yakin bahwa prinsip dialogis naturalistik yang muncul di Lohengrinand mengatur idiom Ring dan karya berikutnya adalah sebuah kesalahan mendasar, opera yang berkembang tepatnya di konsesi untuk kecerdasan musik-formal, dalam keseimbangan dinamis dengan nilainilai kebenaran yang dramatis dan ekspresi puitis (Sams, 1975:867). Di sisi lain, adalah mungkin bahwa (seperti yang disarankan Eric Sams) ia menghina Judaisme Music (1850) milik Wagner bahkan sebelum, atau terpisah dari, saluran reformasi operabudaya dan sebelum mengenal Lohengrin dan musik drama berikutnya. Penghinaan ini menjadi masalah pribadi langsung dengan pembacaan rancangan Die Meistersinger yang terkenal di rumah Josef Standhartner pada tahun 1862 di hadapan Hanslick (Beckmesser disebut Veit Hanslich pada saat itu), dan dengan gesekan mengerikan kepada Hanslick dan Vom MusikalischSchönen dalam kata pengantar untuk edisi 1869 dari esai "Judaisme" (Aufklärungen über das Judenthum in der musik), di mana Wagner menggambarkan dalil keindahan musik otonom sebagai semacam konspirasi ideologis untuk mempromosikan cita-cita dari budaya musik 'agama Yahudi' (warisan Mendelssohn dan Schumann) terhadap orang-orang dari the Gesamtkunstwerk (Payzant, 1989:130).

Edisi asli risalah Hanslick dibuat hanya dengan menyebutkan tulisan Wagner atau operanya (membandingkan Lohengrin 
dengan tidak baik dengan Tannhäuser, misalnya). Komentar yang meremehkan ideide Wagner dan karya-karyanya diakumulasi dengan edisi berikutnya, yang pertama bertepatan dengan Ulasan negatif Hanslick yang pertama tentang komposer (produksi pertama Lohengrinin 1858 di Wina). Antara tahun itu dan 1862 'Kasus Beckmesser' di Wina tentang antagonisme antara kritikus dan komposer dipadatkan; periode yang sama melihat perdebatan 'musik dari masa depan' mencapai tingkat paling keras dan paling sengit mereka dalam pers musik. Setelah titik ini, sulit untuk mengetahui apa yang mungkin telah dibuat oleh Hanslick pada output Wagner tanpa ada masalah kebencian pribadi (dan kebenciannya kepada persona retoris publik). Ia jelas, dan bisa ditebak, lebih memilih Die Meistersinger ke Tristan und Isolde (meskipun dari Beckmesser). Ia kemudian menyesal, secara pribadi, beberapa kritik meremehkan yang ia buat dari bekas pekerjaan utamanya (menghadapkannya pada batas waktu akhir dan stres pribadi), namun ia tidak repotrepot merevisi kritik tersebut ketika ia meninjau Die Meistersinger di Wina dua tahun kemudian. Ia membela dirinya melawan karikatur Beckmesser menegaskan bahwa ia tidak pernah menyerang Wagner dengan detail yang bertele-tele pada harmonik yang dirasakan atau pelanggaran kontrapungtal tetapi hanya pada prinsipprinsip umum dari gaya dan dramaturgi, atau mungkin pelanggaran logika dramatis dan logikanya (Grey, 1994:55).

Rangkaian komunikasi ke Neue Freie Presse pada 1876 dalam premier dari siklus Ring di Bayreuth (dicetak ulang di Musikalische Stationen) memberikan kesan yang baik dari pandangan Hanslick pada Wagner, termasuk upaya untuk menjadi adil dan objektif. Diksi puitis teks yang 'terpengaruh', penekanan pada simbol dan saran psikologis yang tidak jelas tentang pengorbanan alam dan eksposisi 'logis', dan suasana umum pemujaan, pseudokeagamaan membuat kagum sekitar acara tersebut (seperti dengan Parsifal di berikutnya) membangkitkan penghinaan yang lebih pada pengaturan musik yang sebenarnya dari tetralogi tersebut. Kejeniuasn Wagner pada 'gambar' sketsamusik yang efektif memunculkan kekaguman Hanslick sekali lagi (ia berbicara tentang komposer sebagai regisseur musik yang besar, berbeda dari kegagalan sebagai dramawan). Semua manifestasi teori 'reformasi' dari opera, di sisi lain, memprovokasi kecaman. Aplikasi skala penuh atas motif musik asosiatif diberhentikan sebagai percobaan tak berseni (Hanslick tampaknya menjadi salah satu yang menciptakan gambar populer dari indeks tematik Wolzogen sebagai 'panduan musik Baedeker'). Hilangnya melodi vokal yang dibentuk dengan independen demi sebuah melodi orkestra 'tak berujung' menyalahgunakan fragmen leitmotivic sehingga dianggap sebagai dosa utama 'musik drama' Wagner, bersama-sama dengan kurangnya ensemble dan paduan suara. Ia menemukan hal kecil untuk menghargai konsepsi Wagner tentang monolog dramatis atau dialog sebagai bentuk musik yang secara bebas berkembang didukung oleh komentar bermotif psikologis di orkestra (Grey, 1988:36-37).

Dalam kritiknya kepada Wagner di kemudian hari, Hanslick berulang kali menggunakan metafora dari fisik dan mental 'patologi'. Ia mencela gejala penyakit budaya dan pembusukan Wagner, sisi atavistik dan anti-rasional modernisme bahwa ia dan banyak orang lain dianggap sebagai ancaman yang tidak hanya tradisi, tetapi juga untuk kesehatan, pragmatis, aspek 'progresif' dari borjuis modern budaya (resistensinya untuk simfoni Bruckner didasarkan pada tanggapan yang sama, dan ada sedikit keraguan bahwa ia justru sensitif terhadap kualitas Wagner dan Bruckner yang akhirnya akan menarik bagi maha suci 
mistis yang diwarnai dari etos fasis) (McColl, 1997:98).

Siapa pun sangat mudah untuk menyalahkan Hanslick atas ketidaktahuan yang disengaja pada dimensi simbolis dan psikologis karya Wagner, pendekatan mendalam inventif mereka untuk kemajuan harmonik atau konsepsi tidak pasti mereka dari bentuk musik. (Seperti kebanyakan kritikus musik 'progresif' di zamannya, Hanslick diberikan keahlian orkestrasi, meskipun berbicara tentang 'aroma menarik' atau 'pesona kesurupan'-nya, ia mendapatkan pujian kembali.) Beberapa kritiknya, bagaimanapun, lebih sulit untuk dibantah, seperti sering adanya diksi yang buram, dipersembahkan lebih lanjut yang dapat diakses oleh pengaturan musik. Bagaimanapun besar sasarannya, keputusannya sering muncul di belakang, prediksinya (dari 1.883 'epilog' untuk esai tentang Parsifal dan pada kepergian Wagner) yang waktu yang tidak terlalu jauh dari sekarang jelas akan mengakui bahwa ia tidak sehat, lebih-halus, dan merusak kualitas puisi dan musiknya ditanggung cukup akurat oleh generasinya setelah Perang Dunia I (Grey, 1998:39-40).

Sebuah konsekuensi logis dari kritik Hanslick tentang Wagner dan Wagnerism adalah perlawanan kepada meningkatnya wacana chauvinistik kritik musik Jerman pada paruh kedua abad ke-19 dan pertahanan yang konsisten dari opera Prancis dan opéra Comique, termasuk karyakarya yang lebih sukses dari: Auber, Meyerbeer, Halevy, Thomas, dan Gounod. Bias awal terhadap repertoar Italia bel canto dan opera Verdi melunak dengan berjalannya waktu, karena beberapa dari karya-karya ini memasuki kanon internasional. Posisi skeptis nya terhadap budaya 'politik identitas' nasionalis asal Bohemia pada abad ke-19, di sisi lain, mencerminkan rasanya sendiri sebagai identitas warga negara Austria dan kosmopolitan. Pada sebagian besar pendapat tersebut, seperti dalam sikapnya terhadap Wagner dan 'Jerman Baru', Hanslick adalah juru bicara perwakilan untuk penonton di Wina dan di luar (McColl, 1997:86). Ia menghargai kualitas yang membuat opera atau karya konser yang sukses dengan masyarakat, bahkan saat ia berkomitmen untuk mendidik selera populer, dan memperbaikinya (atau setidaknya mengambil masalah dengan itu) ketika ia merasa perlu. Kesenangan yang jelas dalam koordinasi yang efektif dari musik, drama dan tontonan di opera, dan komentarnya yang tak terhitung pada ekspresi tepat (atau tidak tepat) teks puitis dan situasi dramatis dalam karya yang ia ulas, mendustakan kesalahpahaman populer Hanslick sebagai pemasok dari beberapa modernis atau keyakinan formalis dari 'musik murni' karena ia secara eksplisit dan berulang kali berbicara tentang opera sebagai media hybrid yang harus dievaluasi dengan tepat.

Di sisi lain, skeptisisme ke arah musik program modern bahkan oleh komposer yang ia perjuangkan, seperti Dvořák, tetap konsisten dengan pandangan artikulasi dalam Vom Musikalisch-Schönen, musik instrumental bukan media representasional, dan bahwa impuls representasional cenderung mengalihkan perhatian kedua komposer dan pendengar dari musik sifat sejati sebagai bentuk yang 'indah' dan bebas atau ekspresif abstrak (Ridley, 2004:64). Menurut pendapat ini ia melihat dirinya sebagai selaras dengan puisi romantis Robert Schumann bukan sebagai seorang yang sombong dan berdarah dingin 'klasik' yang diperankan oleh musuh-musuhnya. Secara keseluruhan, rasa sayang Hanslick untuk tradisi klasik-Romantis baru-baru ini dan tujuannya untuk berbicara bagi pendengarnya, sementara juga mencoba untuk mendidik mereka untuk apa yang terbaik (oleh bimbingannya) dalam musik baru, menunjukkan angka lebih dekat ke Hans Sachs daripada Beckmesser (Clapham, 1971:246-247; Budd, 1980:30). 


\section{Penutup}

Salah satu kritik paling pedas pernah dilontarkan Hanslick terhadap simfonisimfoni Anton Bruckner sebagai "ular besar simfoni", dan lebih lanjut dikatakan bahwa Bruckner, adalah: "pengkhayal kasar sejenis duapuluh latihan Tristan seorang anggota orkestra". Karena kritik Hanslick selalu mengganggu, maka ketika menerima bintang jasa dari Kaisar Austria-Franz Josef, Bruckner mempunyai satu permohonan kepada Kaisar: "Harap baginda melarang Hanslick mengkritik saya" (Dungga, 1995:199); namun Hanslick tidak bergeming, tetap mengkritisinya.

Cerita di atas merupakan gambaran betapa kuat seorang Hanslick dalam memegang teguh ideologinya. Apa tujuan dari musik, bagi Hanslick pertanyaan tersebut dianggap berlebihan dan tidak perlu ada. Karena menurutnya, pada dasarnya bermain atau mencipta musik merupakan proses alamiah sebagai sarana bagi manusia sejak zaman purbakala untuk mengungkapkan perasaan batinnya dalam bentuk suara tanpa memikirkan suatu maksud dan tujuan tertentu. Dari ideologi estetika absolut tersebut, Hanslick melontarkan kritik-kritik yang tajam terhadap kaum komposer musik programa yang telah dianggapnya menipu pendengar dengan "musik untuk sesuatu"nya. Hakikat musik adalah "suara" (sound) bukan pada "untuk sesuatu-nya".

\section{Referensi}

Bowie, Andrew, "Music Aesthetics and Critical Music", J.P.E. Harper-Scott and Jim Samson (eds.), 2009, An Intoduction to Music Studies, Cambridge: Cambridge University Press, hal. 7991.

Sunarto, "Pemikiran Hanslick tentang Estetika ..." 93
Budd, M., "The Repudiation of Emotion: Hanslick on Music", British Journal of Aesthetics, xx, 1980, hal. 29-43.

Clapham, J., “Dvořák's Relations with Brahms and Hanslick", MQ, lvii, 1971, hal. 241-254.

Deas, S., 1972, In Defence of Hanslick, London.

Dungga, J.A., 1995, Komposer-komposer Perebut Dunia, Jakarta: Puspaswara.

Grey, T., “Eduard Hanslick on Wagner's, Beethoven', Wagner", xv, 1994, hal. 51-57.

Grey, T., "Eduard Hanslick on Wagner's "Actors and Singers"', Wagner, xix, 1998, hal. 34-40.

Hall, R.W., “On Hanslick's Supposed Formalism in Music", Journal of Aesthetics and Art Criticism, xxv, 1966-1967, hal. 433-436.

Hall, R.W., "Hanslick and Musical Expressiveness", Journal of Aesthetic Education, xxix, 1995, hal. 85-92.

Hanslick, Eduard, 1891, The Beautiful in Music, translated by Gustav Cohen, London: Novello and Company Ltd.

Kivy, P., 1993, The Fine Art of Repetition: Essays in the Philosophy of Music, Cambridge: Cambridge University Press.

Maus, F.E., "Hanslick's Animism”, JM, x, 1992, hal. 273-292.

McColl, S., 1997, Music Criticism in Vienna 1896-1897, Oxford: Oxford University Press. 
Payzant, G., "Hanslick, Heinse and the Moral Effects of Music", MR, xlix, 1988-1989, hal. 126-133.

Payzant, G., "Hanslick on Music as Product of Feeling", JMR, ix (1989), hal. 133167.

Ridley, Aaron, 2004, The Philosophy of Music: Theme and Variations, Edinburgh: Edinburgh University Press.
Sams, E., "Eduard Hanslick, 1825-1904: The Perfect Anti-Wagnerite", MT, cxvi, 1975, hal. 867-868.

Stock, Kathleen, 2007, Philosophers on Music: Experience, Meaning, and Work, Oxford: Oxford University Press. 